\title{
Menumbuhkan Pola Hidup Sehat Dan Cinta Lingkungan Di Masa Pandemi Covid-19
}

\author{
Imaniar Resha Erfana ${ }^{1}$, Khomarudin Kamsina ${ }^{2}$ \\ IAIN Syekh Nurjati Cirebon \\ ${ }^{1}$ e-mail: imaniarreshaerfana@gmail.com \\ 2e-mail: khomarudin@syekhnurjati.ac.id \\ *Corresponding Author
}

\begin{abstract}
ABSTRAK
Pandemi ini memberikan banyak dampak bagi kehidupan masyarakat, baik dalam bidang ekonomi, pendidikan, sosial dan budaya dan bahkan psikologis masyarakat. Kegiatan pengabdian dilakukan sebagai upaya untuk menumbuhkan pola hidup sehat dan cinta lingkungan di masa pandemi Covid-19 dalam mendukung pencapaian kehidupan yang baik dan harmonis. Kegiatan ini diselenggarakan bersamaan dengan kegiatan pengabdian ketika Kuliah Kerja Nyata di Desa Klayan Kecamatan Gunung Jati, Kabupaten Cirebon melalui teknik pengumpulan data yaitu wawancara. Hasil wawancara menunjukan, kesehatan dan kecintaan terhadap lingkungan dapat saling berkaitan. Dimana kesehatan tidak hanya meliputi jasmani, tetapi juga rohani yang akhirnya hal tersebut bisa mendorong untuk mencintai lingkungan baik lingkungan alam maupun sosial budaya. Menumbuhkan untuk hidup sehat dengan kegiatan; (1) Membiasakan berolahraga; (2) Membuat makanan sehat yang kreatif; (3) Memberikan edukasi; (4) Mengatur pola hidup. Adapun kegiatan untuk menumbuhkan cinta lingkungan adalah; (1) Melestarikan lingkungan alam dengan penghijauan; (2) Melestarikan kebudayaan daerah; (3) Membiasakan anak - anak untuk berkreasi dengan lingkungan; (4) Membiasakan bersosialisasi dengan masyarakat.
\end{abstract}

Kata Kunci: Pola Hidup Sehat; Lingkungan; Pandemi Covid-19

\begin{abstract}
This pandemic has had many impacts on people's lives, both in the economic, educational, social and cultural fields and Even the psychological community. The service activity is carried out as effort to foster a healthy lifestyle and love the environment during the Covid-19 pandemic in supporting the achievement of a good and harmonious life. This activity was held in conjunction with service activities during the Real Work Lecture in Klayan Village, Gunung Jati District, Cirebon Regency through data collection techniques, namely interviews. The results of the interview show that health and love for the environment can be related. Where health does not only include physical, but also spiritual health, which in the end can encourage love for the environment, both the natural and socio-cultural environment. Cultivate for a healthy life with activities; 1) Get used to exercising; 2) Creating creative healthy foods; 3) Providing education; 4) Regulate the pattern of life. The activities to foster love for the environment are; 1) Preserving the natural environment by reforestation; 2) Preserving local culture; 3) Familiarize children to be creative with the environment; 4) Get used to socializing with the community.
\end{abstract}

Keywords: Healthy Lifestyle; Environment; Covid-19 Pandemic 


\section{PENDAHULUAN}

Menurut Undang - Undang nomor 36 Tahun 2009, kesehatan diartikan sebagai keadaan sehat, baik secara fisik, mental, spiritual maupun sosial untuk memungkinkan setiap orang untuk hidup produktif secara sosial dan ekonomi (Triyono \& Herdiyanto, 2017). Sementara itu, menurut (Susanti \& Kholisoh, 2018) kesehatan diartikan sebagai kondisi fisik, mental, dan sosial yang terbebas dari gangguan penyakit sehingga aktivitas yang berjalan di dalamnya dapat terjadi secara optimal. Dari hal tersebut, dapat disimpulkan bahwa kesehatan adalah suatu kondisi fisik, mental, sosial, maupun spiritual yang baik, sehingga mampu membuat manusia merasa nyaman dan bisa melakukan aktivitas sehari-hari. Oleh karena itu, kesehatan merupakan hal penting yang diinginkan oleh setiap orang. Dengan sehat, seseorang dapat terhindar dari berbagai macam penyakit dan dapat beraktivitas setiap harinya. Namun, dalam beberapa bulan ini Indonesia menghadapi masalah besar yang mengancam kesehatan bahkan nyawa warganya. Bukan hanya Indonesia, tapi hampir seluruh dunia menghadapi masalah yang sama yaitu virus Corona (covid19). Pada akhir Januari 2020 WHO menetapkan status Global Emergency pada kasus virus Corona dan menamakannya sebagai COVID-19 pada 11 Februari 2020 (Handayani, Hadi, Isbaniyah, Burhan, \& Agustin, 2020). Rasanya nama virus ini sudah tidak asing lagi, karena banyak orang yang terkena dampaknya baik secara langsung maupun tidak langsung.

COVID-19 atau virus Corona pertama kali muncul di Wuhan, Cina dan penyebarannya sangat cepat dan mematikan, melalui kontak langsung fisik manusia yang ditularkan lewat mulut, hidung dan mata (Syafrida \& Hartati, 2020). Oleh karena itu banyak orang yang resah, takut dan khawatir akan adanya virus tersebut. Bahkan adanya kejadian ini menghambat aktivitas masyarakat dalam melaksanakan kegiatan sehari-hari seperti biasanya yaitu sekolah, bekerja, berdagang dan lainnya.

Aktivitas keramaianpun di tutup, banyak aturan yang harus dipenuhi oleh masyarakat agar bisa menjaga jarak (social distancing). Orang - orang tidak boleh berkerumun, berdekatan, bahkan beberapa tempat umum di tutup akibat adanya virus ini. Tentunya hal ini juga dilakukan untuk kebaikan bersama yaitu mencegah penularan covid-19. Tetapi tetap saja dampak yang dirasakan masyarakat juga besar, seperti kondisi keuangan yang memburuk, aktivitas sosial yang terganggu, dan kekhawatiran masyarakat akan penularan virus ini. Saat ini, bekerja dari rumah dan belajar dari rumah merupakan salah satu alternatif yang bisa dilakukan demi kebaikan bersaman. Namun, semua pekerjaan yang dilakukan di rumah mungkin membuat sebagian masyarakat merasa kesulitan, bosan dan khawatir tidak bisa berjalan secara optimal. Terutama generasi muda yang saat ini seharusnya berkembang dengan pembelajaran yang aktif bersama teman- teman di sekolah tapi kini harus belajar dari rumah. 
Situasi yang sama dirasakan oleh warga RT 03/ RW 01 Desa Klayan, Kecamatan Gunung Jati, Kabupaten Cirebon yang berdasarkan hasil wawancara, masyarakat nya masih merasa khawatir akan adanya virus ini. Beberapa kegiatan terhambat, bahkan beberapa orang tua kesulitan menghadapi anak - anaknya yang melakukan pembelajaran dari rumah yang kurang kondusif dan mendukung perkembangan anak. Tentunya hal tersebut mengganggu kesehatan tumbuh kembang anak. Melihat situasi lingkungan yang seperti ini, akan sangat baik jika masyarakat dapat menjaga kesehatan mereka dengan mematuhi aturan yang ada dan melakukan perubahan pola hidup ke arah yang lebih baik. Perubahan pola hidup tersebut dilakukan dengan cara menumbuhkannya pada pengetahuan dan kesadaran masyarakat. Tetapi bukan hanya pola hidup sehat yang harus ditumbuhkan, rasa cinta terhadap lingkungan juga perlu. Saat seperti ini tolong - menolong, kepedulian, rasa empati sangat diperlukan. Karena pada hakekatnya kita hidup sebagai makhluk sosial yang memerlukan bantuan orang lain dan kita sebagai warga negara Indonesia yang memegang prinsip nilai - nilai Pancasila seperti, gotong - royong, kerjasama, kepedulian dan sebagainya. Kepedulian terhadap lingkungan sekitar dapat dijadikan alternatif bagi masyarakat di masa pandemi seperti ini. Karena lingkungan adalah tempat kita tinggal, dan sudah sepatutnya kita memiliki rasa cinta dan peduli terhadap lingkungan.

Adapun pengertian lingkungan menurut Yudi Utomo dalam (Napitupulu, Sinaga, \& Syaukani, 2018) adalah segala sesuatu yang ada disekitar kita, hidup dan kehidupan manusia tidak pernah terlepas dari pengaruh lingkungan. Sedangkan menurut Ngalim Purwanto dalam (Masdudi, 2018) bahwa lingkungan meliputi lingkungan alam, lingkungan dalam, dan lingkungan sosial. Sementara itu, menurut Mustofa (2010) bahwa lingkungan adalah semua faktor luar, fisik dan biologis yang secara langsung berpengaruh terhadap ketahanan hidup, pertumbuhan, perkembangan, dan reproduksi organisme (Narut \& Nardi, 2019).

Dari ketiga pengertian yang dikemukakan oleh para ahli, dapat disimpulkan bahwa lingkungan adalah segala sesuatu yang ada di sekitar kita yang berkaitan dengan tempat, peristiwa, dan sosial baik internal maupun eksternal yang mempengaruhi manusia atau dipengaruhi oleh manusia saat berada di dalamnya.

Oleh karena itu, pengertian lingkungan sangat luas mencakup hal - hal yang ada disekitar kita. Jadi, lingkungan yang dimaksud bukan hanya lingkungan alam tetapi juga lingkungan dalam, dan lingkungan sosial - budaya yang perlu ditumbuhkan saat ini. Rasa cinta kepada lingkungan sekitar berarti peduli terhadap peristiwa dan apa yang terjadi di lingkungan, sehingga ini mencerminkan sikap gotong - royong terhadap sesama manusia dan rasa peduli terhadap sesama makhluk hidup. Dengan adanya kegiatan Kuliah Kerja Nyata Dari Rumah (KKN-DR), penulis 
berharap dapat melaksanakan kegiatan yang bermanfaat bagi masyarakat sekitar dan menumbuhkan pola hidup sehat dan cinta lingkungan di masa pandemi covid-19 ini.

\section{METODE PENELITIAN}

Penelitian ini dilaksanakan di Desa Klayan RT 03 / RW 01 Kecamatan Gunung Jati, Kabupaten Cirebon. Pendekatan penelitian yang digunakan adalah penelitian kualitatif dengan jenis penelitian deskriptif. Sementara itu, teknik yang digunakan adalah teknik wawancara, dengan instrumen penelitian berupa catatan dan pedoman wawancara yang digunakan untuk mengetahui sejauhmana tingkat pengetahuan masyarakat tentang cara menumbuhkan pola hidup sehat dan cinta lingkungan serta sejauhmana pengamalan dalam kehidupan sehari - hari. Adapun pedoman wawancara yang digunakan adalah sebagai berikut :

Pola hidup sehat

1. Mengapa pola hidup sehat penting?

2. Bagaimana cara menumbuhkan pola hidup sehat dalam kehidupan sehari - hari?

3. Apakah cara - cara tersebut sudah dilakukan setiap hari?

4. Bagaimana pendapat tentang situasi pandemi seperti ini, apakah ada tips menghadapi masalah seperti ini?

Cinta lingkungan

1. Mengapa rasa cinta terhadap lingkungan sekitar perlu ditanamkan?

2. Bagaimana cara menumbuhkan rasa cinta terhadap lingkungan?

3. Apakah cara tersebut sudah cukup untuk melestarikan lingkungan?

4. Apakah ada cara agar generasi muda sekarang bisa mencintai lingkungan?

\section{PEMBAHASAN}

\section{Pola Hidup Sehat}

Menurut (Ekowarni, 2001) bahwa dalam psikologi kesehatan banyak penyakit yang di sebabkan oleh kebiasaan atau gaya hidup. Sementara itu, Anne Ahira (2011) dalam (Febriani \& Nasution, 2018) mengemukakan bahwa pola hidup sehat mempunyai peranan penting untuk meningkatkan dan mempertahankan kebugaran jasmani seseorang. Dari dua hal yang telah dikemukakan, keduanya saling berkaitan dan dapat disimpulkan bahwa penyebab penyakit adalah kebiasaan atau gaya hidup dan cara untuk menghindarinya adalah dengan melakukan pola hidup sehat untuk meningkatkan kebugaran jasmani dan mempertahankan kesehatan dari berbagai penyakit yang menyerang tubuh kita. 
Oleh karena itu, dapat diketahui bahwa untuk membangun kesehatan dimulai dari kebiasaan baik yang dilakukan oleh seseorang. Berdasarkan hasil wawancara di lapangan, hampir semua narasumber mengetahui tentang pentingnya pola hidup sehat dan cara melakukannya. Akan tetapi masih dinilai kurang. Hal ini bisa dilihat dari hasil wawancara didapatkan hanya beberapa aspek yang sering disebutkan oleh masyarakat terkait pola hidup sehat yaitu : 1) Makanan yang sehat, 2) Berolahraga, 3) Istirahat yang cukup. Oleh karena itu, masyarakat perlu mengetahui cara menumbuhkan pola hidup sehat lainnya, selain ketiga hal tersebut. Selain itu, pengalaman dan kebiasaan terkait pola hidup sehat perlu ditumbuhkan pada masyarakat.

Berikut penuturan dari salah satu narasumber :

W : "Menurut ibu, mengapa pola hidup sehat sangat penting?"

$\mathrm{N} \quad$ : "Ya sangat penting, karena kan kalau sehat berarti ga sakit, orang sakit kan ga enak, ga bisa ngapa-ngapain"

W : "Iya ya Bu, tapi bagaimana menurut ibu cara menumbuhkan pola hidup sehat?"

$\mathrm{N} \quad$ : "Caranya ya dengan rajin berolahraga, makan - makanan yang bergizi, terus istirahat yang cukup"

W : "Oke, terus apakah kegiatan itu udah dilakukan setiap hari?

$\mathrm{N} \quad$ : "Oh ya sudah"

W : : "Olahraga juga setiap hari?"

N : "Ya engga sih, kadang kalau hari Sabtu Minggu paling kalau jalan - jalan"

W : "Iya, terus kan kalau melihat kondisi sekarang ya Bu, lagi masa pandemi virus Covid-19, ada tips ga sih buat menghadapi masalah ini?"

$\mathrm{N} \quad$ : "Ya ada, tentunya dengan waspada, hati - hati, kan yang namanya penyakit juga ga ada yang tau ya, ya waspada ajalah tetap hati - hati aja kalau keluar rumah, rajin berdo'a aja"

Keterangan :

$\mathrm{N}=$ Narasumber

$\mathrm{W}=$ Wartawan

Dari beberapa aspek yang dikemukakan narasumber terkait pola hidup sehat, ada diantaranya hasil temuan selain aspek olahraga, makanan, dan istirahat, yakni adalah berdo'a. Sementara itu, dari beberapa literatur yang dibaca mengenai pola hidup sehat, diantaranya menurut Irianto (2000:16) yang mengemukakan bahwa untuk mencapai kebugaran dan kesehatan, seseorang harus mengatur makanan, beristirahat secara cukup, dan berolahraga teratur (Suharjana, 2012). Sedangkan menurut Kurniadi (2008) dalam (Sihombing \& Pratama, 2018) bahwa untuk 
memiliki hidup sehat, setiap orang harus memiliki pola perilaku hidup sehat, seperti olahraga secara teratur, mental dan kejiwaan yang seimbang serta istirahat yang cukup. Sementara itu, menurut (Anies, 2019) perilaku pola hidup sehat diantaranya adalah makan dengan menu seimbang, olaraga secara teratur , tidak minum minuman keras maupun narkoba, tidak merokok, istrahat yang cukup, mengendalikan stress.

Oleh karena itu, dari beberapa hal yang dikemukakan di atas, penulis menawarkan beberapa cara untuk menumbuhkan pola hidup sehat di masa pandemi covid-19: 1) Membiasakan berolahraga; 2) Membuat ide makanan sehat yang kreatif; 3) Memberikan pembelajaran mengaji; 4) Memberikan tontonan yang mengedukasi; 5) Membuat jadwal kegiatan.

1) Membiasakan berolahraga

Olahraga merupakan aspek yang sering disebutkan dalam pola hidup sehat. Oleh karena itu, olahraga merupakan kebiasaan baik yang harus ditumbuhkan. Dengan meluangkan sedikit waktu untuk berjalan - jalan atau lari kecil saat pagi di area halaman rumah setelah waktu Shubuh bisa dijadikan alternatif untuk membiasakan berolahraga. Tidak harus berolahraga yang secara maksimal tetapi cukup dan teratur dapat meningkatkan kebugaran jasmani kita.

Selain itu, menumbuhkan kebiasaan berolahraga juga perlu diterapkan oleh anak - anak yang sedang dalam masa pertumbuhan. Salah satu kegiatan yang dilaksanakan di Desa Klayan yaitu mengajak anak - anak senam ria. Dengan tetap memperhatikan protokol kesehatan, anak - anak dapat ceria berolahraga bersama teman - teman sebayanya. Karena olahraga bukan hanya soal jasmani, tapi psikis juga sehingga dapat menghibur dan memberikan semangat pada anak - anak di masa pandemi saat ini.

2) Membuat ide makanan sehat yang kreatif

Saat masa pandemi seperti ini, banyak hal yang dilakukan dari rumah. Tentunya waktu di rumah lebih banyak dari pada di luar. Membuat makanan sehat bisa dijadikan alternatif bagi ibu rumah tangga / wanita karir untuk berkreasi. Karena makanan yang dibuat sendiri jauh lebih terjamin kesehatannya dibandingkan makanan cepat saji diluar sana.Kegiatan demonstrasi penyajian makanan atau minuman sehat yang dilakukan di Desa Klayan merupakan salah satu pengabdian yang dilakukan untuk mengajak para wanita untuk bisa berkreasi di rumah dengan membuat makanan sehat yang kreatif.

3) Memberikan pembelajaran mengaji

Seperti yang sudah dikemukakan sebelumnya hasil temuan di lapangan bahwa kesehatan bukan hanya soal jasmani tetapi juga rohani yaitu dengan cara berdo'a. Jika rohani sehat maka dapat mendorong kesehatan - kesehatan lainnya. Pembelajaran mengaji merupakan salah satu alternatif yang dapat dilakukan agar masyarakat dapat sadar akan pentingnya 
mengaji untuk kesehatan rohani. Seperti pembelajaran mengaji yang dilakukan untuk agar anak - anak dapat melek Al - Qur'an sejak dini. Selain itu, pembelajaran mengaji dapat meningkatkan kesadaran dan keimanan agar selalu bersyukur dan menjaga kesehatan mental mereka.

4) Memberikan tontonan edukasi

Menonton merupakan salah satu aktivitas yang dapat dilakukan di waktu luang saat di rumah. Dengan memberikan tontonan yang mengedukasi, dapat memberikan pengetahuan, dan pola pikir ke arah yang lebih baik. Pembelajaran bagi anak - anak juga dapat dilakukan dengan memberikan tontonan yang positif dan menarik yang dapat memberikan stimulus pada pertumbuhan dan perkembangan anak. Hasil pengabdian di lapangan, bahwa anak anak merespon baik pada saat diberikan tontonan animasi tentang kesehatan. Hal ini dapat diketahui bahwa tontonan juga dapat berpengaruh terhadap perkembangan pengetahuan anak, sehingga dapat menumbuhkan kesadaran untuk hidup sehat sejak dini.

5) Membuat jadwal kegiatan

Membuat rencana atau jadwal kegiatan dapat dilakukan agar bisa memanfaatkan waktu dengan baik. Banyak waktu yang dilakukan di rumah membuat sebagian orang mungkin bingung harus melakukan apa, padahal dari sinilah pola hidup sehat dapat dibentuk. Kedisiplinan, kebiasaan yang dilakukan dari jadwal kegiatan memberikan banyak manfaat dalam kesehatan kita juga. Dengan membagi proporsi waktu antara kegiatan, istirahat, dan hiburan dapat membantu terbentuknya pola hidup sehat. Dengan demikian, hal - hal lain dapat dilakukan tanpa mengurangi atau melebihi waktu yang sebaiknya.

Misalnya waktu istirahat sebaiknya yang cukup tidak berlebihan dan tidak pula kekurangan. Dari hasil wawancara, salah satu yang sering disebutkan adalah istirahat. Menurut (Sutanto \& Fitriana, 2017) istirahat merupakan suasana yang tenang, bersantai tanpa tekanan emosional dan bebas dari kecemasan (ansietas). Oleh karena itu, istirahat yang cukup juga penting untuk badan dan pikiran kita. Akan tetapi mungkin sebagian orang meninggalkannya karena ada hal lebih penting yang harus dikerjakan. Oleh karena itu salah satu cara agar bisa melakukannya adalah dengan membuat jadwal kegiatan.

\section{Cinta Lingkungan}

Cinta lingkungan merupakan suatu sikap atau karakter peduli terhadap lingkungan. Rasa cinta lingkungan ini perlu ditumbuhkan pada masyarakat, apalagi generasi muda. Karena hakekatnya manusia tinggal dan berada dalam sebuah lingkungan, yang patut untuk dipedulikan, dijaga dan dilestarikan. Berdasarkan hasil wawancara dengan narasumber, bahwa rata- rata 
pengetahuan masyarakat tentang lingkungan masih dinilai kurang, hal ini dapat dilihat dari hasil yang dikemukakan masyarakat masih tentang seputar lingkungan hidup. Padahal ruang lingkup lingkungan sangatlah luas.

Berikut ini beberapa yang dituturkan oleh salah satu narasumber :

W : "Menurut ibu, mengapa rasa cinta kepada lingkungan perlu ditanamkan?"

$\mathrm{N} \quad$ : "Karena kan supaya melestarikan lingkungan, supaya ngga rusak, bisa di tempati sampe anak cucu"

W : "Iya, tapi gimana cara menumbuhkan rasa cinta kepada lingkungan sekitar?"

$\mathrm{N} \quad$ : "Cara menumbuhkannya ya dengan membuang sampah pada tempatnya, rajin bersih - bersih"

W : "Apakah hal tersebut sudah cukup untuk melestarikan lingkungan?"

N : : Ya insyallah cukup"

W : : Kira - kira ada cara ngga sih Bu supaya generasi muda bisa mencintai lingkungan?"

$\mathrm{N} \quad$ : "Caranya ya dengan menasehati kalau lingkungan juga penting"

Keterangan :

$\mathrm{N} \quad=$ Narasumber

$\mathrm{W}=$ Wartawan

Berdasarkan hasil wawancara, adapun beberapa aspek yang sering disebutkan dalam cara menumbuhkan cinta lingkungan adalah : 1) Kegiatan bersih - bersih;2) Tidak membuang sampah sembarangan. Selain itu, ada beberapa hasil temuan dari masyarakat yaitu ada salah satunya menyebutkan tentang penghijauan tanaman. Kemudian ketika ditanya tentang bagaimana caranya menumbuhkan rasa cinta lingkungan kepada generasi muda, rata - rata masyarakat menjawab dengan cara menasehati, memberitahu dan lainnya. Secara tidak langsung hal ini merupakan hasil temuan dari masyarakat setempat bahwa salah satu caranya adalah melalui pembelajaran.

Sejalan dengan hal itu, berdasarkan literatur yang dibaca diantaranya menurut Uno dan Mohamad mengemukakan bahwa penanaman, pemahaman, dan kesadaran tentang pentingnya menjaga kelestarian kualitas lingkungan sangat baik apabila mulai diterapkan melalui pendidikan (Marjohan \& Afriyanti, 2018).

Abidinsyah (2011) juga mengemukakan bahwa karakter tidak terbangun dengan sendirinya, melainkan harus dibentuk badan ditumbuh kembangkan melalui pendidikan (Elsa, Khairil, \& Yunus, 2014). Oleh karena itu, dapat disimpulkan bahwa selain kegiatan di lingkungan hidup, cara menumbuhkan rasa cinta terhadap lingkungan adalah melalui pendidikan dan pengajaran. Generasi muda memerlukan pengajaran tentang lingkungan dan penanaman nilai - 
nilai kepedulian sejak dini agar bisa mengetahui, memahami dan menerapkan dalam kehidupan sehari-hari. Walaupun di masa pandemi covid-19, tetapi tidak menghalangi pendidikan dan usaha - usaha kepedulian terhadap lingkungan.

Berikut ini beberapa cara untuk menumbuhkan rasa cinta lingkungan dampak covid-19 adalah : 1) Melestarikan lingkungan alam dengan penghijauan; 2) Melestarikan kebudayaan daerah; 3) Memberikan tontonan yang mendidik bagi anak - anak; 4) Membiasakan anak - anak untuk berkreasi dengan lingkungan; 5) Membiasakan bersosialisasi dengan masyarakat.

1) Melestarikan lingkungan alam dengan penghijauan

Saat ini mungkin beberapa aktivitas terhambat demi mencegah penularan virus covid-19, tetapi aktivitas penghijauan tetap bisa dilakukan. Caranya mudah, kita bisa berkebun di area halaman rumah dengan menanam beberapa tumbuhan yang bisa ditanam atau tanaman apotek hidup yang bisa bermanfaat. Kegiatan di Desa Klayan salah satu contohnya yaitu dengan membuat taman apotek hidup. Taman ini bertujuan agar bisa menjadi contoh untuk masyarakat sekitar bahwa kegiatan penanaman penting dan mudah dilakukan. Selain itu, dalam kegiatan ini banyak masyarakat yang menyambut baik dan ikut berpartisipasi dalam mencari tanaman apotek hidup. Oleh karena, itu diharapkan masyarakat dapat melakukan kegiatan penanaman ini selanjutnya.

2) Melestarikan kebudayaan daerah

Dari beberapa pengertian yang telah dikemukakan tentang lingkungan diantaranya lingkungan bukan hanya meliputi lingkungan hidup, melainkan lingkungan sosial - budaya juga termasuk di dalamnya. Lingkungan sosial - budaya yang dimaksud salah satunya adalah kebudayaan daerah dan salah satunya permainan tradisional.

Dari hal yang sederhana yaitu permainan tradisional diharapkan masyarakat terutama anak - anak bisa mencintai lingkungan budaya Indonesia. Dalam permainan tradisional, tentunya terdapat nilai - nilai positif yang didapatkan seperti kerja sama, kekompakkan, ketelitian yang mampu meningkatkan kreativitas dan perkembangan anak. Sejalan dengan hal itu, menurut Maxim (1985) dalam (Nurhayati, 2016) bermain membantu anak dalam mengembangkan banyak aspek fundamental dari perkembangan fisik, intelektual, sosial dan emosional. Oleh karena itu, bermain bagi anak - anak adalah aktivitas yang baik untuk perkembangan anak, apalagi dengan permainan tradisional yang memiliki nilai - nilai kerjasama dan kekompakkan. Karena selain melestarikan budaya, permainan dapat dijadikan alternatif untuk pembelajaran bagi anak - anak di masa pandemi ini. 
3) Kreasi daur ulang

Di era sekarang ini, banyak orang-orang kreatif yang bisa menciptakan sesuatu yang unik. Jika dalam masa pandemi ini lebih banyak di rumah, tidak ada salahnya jika kita bisa berkreasi dengan mendaur ulang sampah plastik atau barang yang tidak berguna menjadi berguna. Selain bisa berkreativitas, kita juga bisa mencintai lingkungan dengan mengurangi sampah plastik. Contohnya kita bisa mendekorasi ruangan dengan botol plastik yang bisa dimanfaatkan menjadi vas bunga dan berbagai hiasan lain. Selain itu, plastik makanan ringan yang dibuat menjadi tas yang bisa dipakai berkali - kali sehingga jika berbelanja tidak memerlukan kantong plastik sekali pakai. Hal ini tentunya bisa mengurangi pengeluaran plastik.

4) Membiasakan bersosialisasi dengan masyarakat

Di masa pandemi ini memang lebih baik jika kita menjaga jarak, tetapi itu tidak menutup kemungkinan untuk bersosialisasi dalam masyarakat. Tidak harus berkumpul dan berkerumun tapi dapat menolong sesama masyarakat yang membutuhkan bantuan, ikut berpartisipasi dalam kegiatan kebersihan dan kesehatan di masa pandemi, dan lainnya bisa dilakukan. Menurut (Yuniarto, 2017) dari sejak lahir sampai meninggal dunia manusia perlu bantuan atau bekerja sama dengan orang lain.

Dari hal tersebut dapat diketahui bahwa manusia adalah mahkluk sosial dan bersosialisasi merupakan kegiatan yang mendorong kita untuk saling mengenal, membantu, dan berempati sesama manusia. Karena pada hakekatnya, setiap orang yang tinggal pasti memiliki lingkungannya masing - masing dan cara menumbuhkan cinta lingkungan sosial adalah menjalin silaturahmi antar sesama masyarakat.

5) Membiasakan tontonan yang mendidik bagi anak - anak

Salah satu hasil temuan di masyarakat, bahwa cara menumbuhkan rasa cinta terhadap lingkungan bagi generasi muda adalah melalui pengajaran. Banyak cara - cara pengajaran yang dilakukan untuk menarik perhatian pembelajar dan memudahkan mereka dalam belajar. Salah satunya adalah melalui tontonan. Di masa pandemi seperti ini, mungkin banyak masyarakat yang memanfaatkan waktu untuk sekedar hiburan yaitu menonton. Tidak ada salahnya jika hal tersebut dilakukan melalui tontonan yang mengedukasi.

Sama halnya dengan menumbuhkan pola hidup sehat, wawasan juga diperlukan dalam kesadaran akan lingkungan, melalui tontonan yang mendidik kepada anak - anak dapat membiasakan cara berpikirnya untuk peduli terhadap lingkungan. Memalui tontonan juga orang tua dapat berkomunikasi dengan anak untuk mengarahkan dan menumbuhkan rasa kasih sayang, empati dan peduli terhadap lingkungan sekitarnya. 


\section{KESIMPULAN}

Pola hidup sehat dan cinta lingkungan dapat ditumbuhkan dengan kebiasaan dan perilaku yang baik. Cara menumbuhkan pola hidup sehat diantaranya adalah 1) Membiasakan berolahraga; 2) Membuat ide makanan sehat yang kreatif; 3) Memberikan pembelajaran mengaji; 4) Memberikan tontonan yang mengedukasi; 5) Membuat jadwal kegiatan. Sementara itu, cara menumbuhkan rasa cinta lingkungan adalah 1) Melestarikan lingkungan alam dengan penghijauan; 2) Melestarikan kebudayaan daerah; 3) Kreasi daur ulang; 4) Membiasakan bersosialisasi dengan masyarakat; 5) Membiasakan tontonan yang mengedukasi bagi anak - anak. Pada masa pandemi Covid-19, banyak sekali dampak yang dirasakan oleh masyarakat. Oleh karena itu, penting sekali untuk menumbuhkan kebiasaan sehat dan cinta lingkungan bagi masyarakat. Agar masyarakat lebih peduli terhadap sesama makhluk hidup dan bisa mencintai dirinya dengan menjaga kesehatan, baik jasmani maupun rohani.

\section{UCAPAN TERIMA KASIH}

Terima kasih disampaikan kepada seluruh unsur masyarakat di Desa Klayan, Kecamatan Gunung Jati, Kabupaten Cirebon yang telah memberikan kesempatan dan banyak mendukung kegiatan pelatihan yang diselenggarakan bersamaan dengan kegiatan Kuliah kerja Nyata ini dapat berjalan lancar.

\section{DAFTAR PUSTAKA}

Anies. (2019). Sehat Tanpa Obat Berbagai Upaya Untuk Tetap Sehat Tanp Tergantung Pada Obat. Yogyakarta: Gosyen Publising.

Ekowarni, E. (2001). Pola Perilaku Sehat Model Pelayanan Kesehatan Remaja. Psikologi, 97 104.

Elsa, F., Khairil, \& Yunus, Y. (2014). Penerapan Pendidikan Karakter Peduli Lingkungan Melalui Metode Inkuiri Terhadap Sikap dan Perilaku Siswa Pada Materi Pencemaran dan Kerusakan Lingkungan di SMP Negeri 6 Banda Aceh. Biotik (2).

Febriani, A., \& Nasution, J. D. (2018). Pola Hidup Sehat Antara Siswa Pada Sekolah Go Green dan Sekolah Tidak Go Green. Pendidikan Olahraga dan Kesehatan (6), 565-568.

Handayani, D., Hadi, D. R., Isbaniyah, F., Burhan, E., \& Agustin, H. (2020, April). Penyakit Virus Corona 2019. Resprilogi Indonesia (40).

Marjohan, \& Afriyanti, R. (2018, Juni). Penerapan Nilai Pendidikan Karakter Peduli Lingkungan di Kelas Tinggi Sekolah Dasar. Gentala Pendidikan Dasar (3), 111-126.

Masdudi. (2018). Dasar - Dasar Ilmu Pendidikan. Cirebon. 
Napitupulu, D. S., Sinaga, A. I., \& Syaukani. (2018, Januari). Implementasi Program Cinta Lingkungan di MAN 2 Model Medan. At-Tazakki (2).

Narut, Y. F., \& Nardi, M. (2019, September). Analisis Sikap Peduli Lingkungan Pada Siswa Kelas VI Sekolah Dasar di Kota Ruteng. Gentala Pendidikan Dasar (9), 259-266.

Nurhayati, E. (2016). Psikologi Pendidikan Inovatif. Yogyakarta: Pustaka Pelajar.

Sihombing, R. M., \& Pratama, E. R. (2018). Hubungan Pola Perilaku Hidup Sehat Dengan Prestasi Akademik Mahasiswa Keperawatan. Nursing Current (6).

Suharjana. (2012, Juni). Kebiasaan Berperilaku Hidup Sehat dan Nilai - Nilai Pendidikan Karakter. Jurnal Pendidikan Karakter.

Susanti, E., \& Kholisoh, N. (2018, Juni). Konstruksi Makna Kualitas Hidup Sehat. Jurnal Lugas (2), 1-12.

Sutanto, A. V., \& Fitriana, Y. (2017). Kebutuhan Dasar Manusia Teori dan Aplikasi Praktik Keperawatan Profesional. Yoyakarta: Pustaka Baru Press.

Syafrida, \& Hartati, R. (2020). Bersama Melawan Virus Covid 19 di Indonesia. Sosial dan Budaya Syar-I (7).

Triyono, S. D., \& Herdiyanto, Y. K. (2017). Konsep Sehat dan Sakit Pada Individu Dengan Urolithias (Kencing Batu) di Kabupaten Klungkung Bali. Psikologi Udayana (4).

Yuniarto, B. (2017). Bunga Rampai Pendidikan Pancasila. Cirebon: CV. Elsi Pro. 